\title{
The Fluorimetric Estimation of $N^{1}$-Methylnicotinamide and its Differentiation from Goenzyme I
}

\author{
BY K. J. CARPENTER* AND E. KODICEK \\ Dunn Nutritional Laboratory, University of Cambridge, and Medical Research Council
}

(Received 31 October 1949)

$N^{1}$-Methylnicotinamide has been shown to be one of the principal excretion products derived from the metabolism of nicotinic acid in man, the dog and the rat (Najjar, Scott \& Holt, 1943; Huff \& Perlzweig, $1943 a, b$; Ellinger \& Coulson, 1943). Various methods have been worked out for its estimation employing adsorption on to, and elution from, an active surface, followed by extraction into a butanol phase. The fluorescence in the butanol layer, that is the $F_{2}$ fluorescence, has then been measured (Huff \& Perlzweig, 1943c; Coulson, Ellinger \& Holden, 1944; Najjar, 1944). Huff, Perlzweig \& Tilden (1945), and Huff \& Perlzweig (1947) have published a new method for the estimation of $N^{1}$-methylnicotinamide, involving the formation of a fluorescence in the presence of acetone in a single aqueous phase. A fluorescence was produced if coenzymes were similarly treated and this method has been used for their estimation in blood (Levitas, Robinson, Rosen, Huff \& Perlzweig, 1947) and animal tissues (Robinson, Levitas, Rosen \& Perlzweig, 1947).

The present paper deals with studies of the optimum conditions for the production of fluorescence of some $N^{1}$-substituted pyridine compounds. A modified procedure has been devised using methyl ethyl ketone instead of acetone, and employing different blanks. The fluorescence due to $N^{\mathbf{1}}$-methylnicotinamide has been differentiated from that of the phosphopyridine nucleotides and $N^{\mathbf{1}}$-methylnicotinuric acid betaine. The interference due to indole has been eliminated.

\section{EXPERIMENTAL $\dagger$}

Principle. $N^{1}$-methylnicotinamide ( $N$-MN) in aqueous alkaline solution reacts with ketones to produce a greenish blue fluorescence; on acidification the fluorescence changes to blue, and is intensified by heating (Huff et al. 1945; Huff, 1947).

Choice of ketone. Several ketones were tested both with water alone and with an aqueous solution of $N^{\mathbf{1}}$-methylnicotinamide chloride (Table 1). We prefer the methyl ethyl ketone to acetone, because it gives higher fluorimeter readings and is less volatile. The time of alkaline treatment

* Present address: Rowett Research Institute, Bucksburn, Aberdeenshire.

$\dagger$ Where not otherwise stated the procedure has been carried out as described in the final method.

and strength of alkali for optimal fluorescence were found to be the same as described for the acetone method (Huff \& Perlzweig, 1947). A 5-min. period was adopted for acid digestion (Table 2). A shorter digestion of $2 \mathrm{~min}$. as recommended in the original acetone procedure was found not to be optimal for the methyl ethyl ketone procedure.

\section{Table 1. Fluorescence of N-MN in the presence of various ketones}

Ketone used

Acetone

Methyl ethyl ketone

Diacetone alcohol

\begin{tabular}{|c|c|}
\hline Fluorimeter & eadings (mm.) \\
\hline Water control & $\begin{array}{l}\text { Water }+0 \cdot 15 \mu \mathrm{g} \text {. } \\
\text { of } N \cdot \mathrm{MN} / \mathrm{ml} .^{*}\end{array}$ \\
\hline $\begin{array}{l}1 \\
1 \\
8 \cdot 5\end{array}$ & $\begin{array}{l}46 \cdot 5 \\
66 \cdot 5 \\
21\end{array}$ \\
\hline
\end{tabular}

* Final concentration as used for fluorimetric readings.

Table 2. Effect of time of digestion on final fluorescence of $0 \cdot 2 \mu g$. of $\mathrm{N}-M N / m l$.

$\begin{array}{ccc}\begin{array}{c}\text { Time of } \\ \text { digestion } \\ \text { (min.) }\end{array} & \begin{array}{c}\text { Average of } \\ \text { five readings }\end{array} & \begin{array}{c}\text { Standard } \\ \text { deviation }\end{array} \\ 2 & 69 & \pm 1 \cdot 5 \\ 4 & 84 & \pm 2 \cdot 9 \\ 6 & 81 & \pm 2 \cdot 1\end{array}$

Acidity of digestion mixture. The fluorescence in methyl ethyl ketone like that in acetone was only slightly altered between $\mathrm{pH} 1$ and 5. An amount of $\mathrm{HCl}$ needed to adjust the solution to $\mathrm{pH} 2$ was used throughout (Table 3).

Table 3. Effect of $\mathrm{pH}$ during acid digestion on fluorescence of $0 \cdot 2 \mu g$. of $\mathrm{N}-M N / m l$.

$\begin{array}{llllllllll}\text { Final } \mathrm{pH} & \ldots & \ldots & \ldots & 1 & 2 & 5 & 7 & 10\end{array}$ $\begin{array}{llllll}\text { Fluorimeter readings }(\mathrm{mm} .) & 86 & 88 & 86 & 73 & 11\end{array}$

Choice of a blank. The use of blue fluorescence, especially with urine, as a measure of a particular compound has the danger of unspecificity. A critical examination of possible blanks was therefore undertaken. Blanks may be prepared in the following ways: (1) omitting the ketone and replacing it by water (Huff et al. 1945), 'water blank'. (2) The addition of the reactants in a different order so that $N$-MN gives no fluorescence, although the final composition of the reactant mixture is unchanged. The blank procedures $2 a, b$ and $c$, given in Table 4 ('delayed ketone blank', 'final ketone blank' and ' no $\mathrm{NaOH}$ blank'), are of this type. The last is included in this group because the omission of both $\mathrm{NaOH}$ and the equivalent of $\mathrm{HCl}$ leaves the final composition of the solu- 
tion altered only in its $\mathrm{NaCl}$ content. (3) The preliminary removal of $N$-MN from the original material by selective adsorption ('decalso blank'). (4) Huff et al. (1945) used charcoal to remove interfering substances. We were unable to secure a suitable type of charcoal which did not also adsorb some of the $N$-MN.

Blanks of types 1 and 2 (Table 4). The blank fluorescence in each case was determined on three test materials: (i) water, (ii) standard $N$-MN solution, and (iii) urine.

With all four of the blanks the fluorimeter readings with pure $N-\mathrm{MN}$ were no greater than with water as the test material. However, urine gave higher readings with all the blanks, particularly those containing ketone. The possibility that $N \cdot \mathrm{MN}$ was causing the higher values for the blanks in the presence of urine, although it did not fluoresce in a simple watery solution, was examined by comparing the fluorescence of blanks for a sample of urine and for the same sample of urine with added $N$-MN (Table 5). Blanks $2 a$ and $2 b$ showed a significant increase with added $N$-MN and could not therefore be recommended. On the other hand, the remaining blanks showed no increase with $N$-MN added to urine.

In further experiments it was found that a trace of acetone (of the order of concentration found in a diabetic urine) increased the 'water blank' significantly, but did not affect the 'no $\mathrm{NaOH}$ blank'. The 'no $\mathrm{NaOH}$ blank' was therefore to be preferred.

Blank of type 3. A blank of type 3 which we investigated was the 'decalso blank'. A column of fresh, but not specially activated, decalso (60-80 mesh, Permutit Co. Ltd.) $10 \mathrm{~cm}$. long and $8 \mathrm{~mm}$. in diameter was prepared and washed with $10 \mathrm{ml}$. of water by suction. The $20 \mathrm{ml}$. sample of test material was adjusted to $\mathrm{pH} \mathbf{5 \cdot 0}$ with glacial acetic acid, then sucked through the column and the filtrate collected. It was found that if the total salinity of the solution did not exceed $0.5 \% \mathrm{KCl}$, more than $98 \%$ of the $N$-MN in the original solution was adsorbed. Thus the filtrate, if treated by the normal procedure parallel with a sample which was not filtered, provided a possible blank.

The blank was found to be applicable to urine (Table 6). This blank fluorescence produced with decalso-filtered urine gave a value similar to that produced with the 'no $\mathrm{NaOH}$ blank'. $N$-MN added to the urine before passing through the decalso column was completely adsorbed, as evidenced by the fact that the intensity of the fluorescence was not increased. Addition of $N$-MN to the filtered urine increased the fluorescence to the same extent as it did when added to unfiltered urine. The 'decalso blank' has never been found

Table 4. Fluorescence of different blanks

\begin{tabular}{|c|c|c|c|c|c|c|c|c|}
\hline \multirow[b]{3}{*}{ Blanks } & \multirow{2}{*}{\multicolumn{5}{|c|}{ Operations, in order }} & \multirow{3}{*}{$\begin{array}{l}\text { Water } \\
\text { control }\end{array}$} & \multirow{3}{*}{$\begin{array}{l}N \cdot \mathrm{MN} \\
(0 \cdot 2 \mu \mathrm{g} . / \\
\text { ml. })\end{array}$} & \multirow{3}{*}{$\begin{array}{l}\text { Urine } \\
(0.1 \mathrm{ml} . \text { in } \\
1 \mathrm{ml} .)\end{array}$} \\
\hline & & & & & & & & \\
\hline & 1 & 2 & 3 & 4 & 5 & & & \\
\hline \multirow{2}{*}{$\begin{array}{l}\text { (1) Water } \\
\text { (2a) Delayed } \\
\text { ketone }\end{array}$} & $\mathrm{NaOH}$ & Wait 5 min. & $\mathrm{HCl}, \mathrm{pH} 2 \cdot 0$ & Digest $5 \mathrm{~min}$. & - & $2 \cdot 0$ & 1.5 & 53 \\
\hline & $\mathrm{NaOH}$ & Wait 5 min. & $\mathrm{HCl}, \mathrm{pH} 2 \cdot 0$ & Ketone & Digest $5 \mathrm{~min}$. & $2 \cdot 5$ & $2 \cdot 5$ & $63 \cdot 5$ \\
\hline (2b) $\underset{\text { ketone }}{\text { Final }}$ & $\mathrm{NaOH}$ & Wait $5 \mathrm{~min}$. & $\mathrm{HCl}, \mathrm{pH} 2 \cdot 0$ & Digest 5 min. & Ketone & $2 \cdot 5$ & $2 \cdot 0$ & 62 \\
\hline (2c) $\underset{\mathrm{NaOH}}{\mathrm{No}}$ & $\mathrm{HCl}, \mathrm{pH} 2$ & Ketone & Digest 5 min. & - & - & $2 \cdot 5$ & $2 \cdot 5$ & $60 \cdot 5$ \\
\hline \multirow[t]{6}{*}{$\begin{array}{l}\text { Full fluores- } \\
\text { cence }\end{array}$} & \multirow[t]{4}{*}{ Ketone } & $\mathrm{NaOH}$ & Wait 5 min. & $\mathrm{HCl}, \mathrm{pH} 2 \cdot 0$ & Digest $5 \mathrm{~min}$. & $2 \cdot 5$ & 97 & 97 \\
\hline & & \multicolumn{6}{|c|}{ Table 5. Examination of blanks in the presence of urine } & \\
\hline & & & \multicolumn{5}{|c|}{ Fluorimeter readings $(\mathrm{mm})}$. & \\
\hline & & & \multicolumn{2}{|c|}{$\begin{array}{l}\text { Urine, } 0.08 \mathrm{ml} . \\
\text { in } 1 \mathrm{ml} .\end{array}$} & $\begin{array}{l}\text { ne }(0.08 \mathrm{ml} .)+ \\
\text { MN, }(0.15 \mu \mathrm{g} .) \\
\text { in } 1 \mathrm{ml} .\end{array}$ & \multicolumn{2}{|c|}{$\begin{array}{c}\text { Increase due to } \\
N-\mathrm{MN}\end{array}$} & \\
\hline & \multicolumn{2}{|c|}{$\begin{array}{ll}\text { (1) } & \text { Water } \\
(2 a) & \text { Delayed ketone } \\
(2 b) & \text { Final ketone } \\
(2 c) & \text { No } \mathrm{NaOH}\end{array}$} & \multicolumn{2}{|c|}{$\begin{array}{l}70 \\
80 \cdot 5 \\
74 \cdot 5 \\
78\end{array}$} & $\begin{array}{l}70 \\
86 \cdot 5 \\
80 \cdot 5 \\
78\end{array}$ & \multicolumn{2}{|c|}{$\begin{array}{ll} & 0 \\
+ & 6 \cdot 5 \\
+ & 6 \cdot 0 \\
& 0\end{array}$} & \\
\hline & \multicolumn{2}{|c|}{ Full fluorescence } & \multicolumn{2}{|c|}{223.5} & $261 \cdot 5$ & & \\
\hline
\end{tabular}

Table 6. Adsorption of N-MN in presence of urine

Fluorimeter readings ( $\mathrm{mm}$.)

Fluorimeter readings (mm.)

Material

Urine, $0.025 \mathrm{ml}$. in $1 \mathrm{ml}$.

Urine, $0.0125 \mathrm{ml}$. in $1 \mathrm{ml}$.

(filtered through decalso column)

\begin{tabular}{|c|c|c|c|}
\hline \multicolumn{4}{|c|}{ Fluorimeter readings $(\mathrm{mm})}$. \\
\hline $\begin{array}{c}\text { Without } \\
\text { added } N \text {-MN }\end{array}$ & $\begin{array}{l}\text { With } \\
(0 .\end{array}$ & $\begin{array}{l}N-\mathrm{MN} \\
\mathrm{ml} .)\end{array}$ & $\begin{array}{c}\text { Increase } \\
\text { with } N \text {-MN }\end{array}$ \\
\hline \multirow[t]{2}{*}{62.5} & & & +88 \\
\hline & $\begin{array}{l}\text { Added before } \\
\text { filtration }\end{array}$ & $\begin{array}{l}\text { Added after } \\
\text { filtration }\end{array}$ & \\
\hline 33 & 32 & $\overline{125 \cdot 5}$ & $\begin{array}{l}-1 \\
+92.5\end{array}$ \\
\hline
\end{tabular}


to be lower than the 'no $\mathrm{NaOH}$ blank', suggesting that none of the non-specific fluorescing substances in urine were adsorbed on the decalso column.

\section{FINAL METHOD}

Experience with both rat and human urines has shown that there was very little difference between 'decalso' and 'no $\mathrm{NaOH}$ ' blanks, and for routine examinations of these materials the simpler ' $\mathrm{no} \mathrm{NaOH}$ ' technique will first be described. Precautions other than those described below were taken according to Huff \& Perlzweig (1947).

\section{Final procedure 1 ('no $\mathrm{NaOH}$ blank')}

Reagents required. (1) Methyl ethyl ketone; (2) $5 \mathrm{~N}-\mathrm{NaOH}$; (3) $5 \mathrm{~N}-\mathrm{HCl}$; (4) $20 \% \mathrm{KH}_{2} \mathrm{PO}_{4}$ solution.

Standard $\mathrm{N}^{1}$-methylnicotinamide solution: (1) stock standard solution, $0.5 \mathrm{mg} . / \mathrm{ml}$. of $N^{1}$-methylnicotinamide ion, made by dissolving $31.35 \mathrm{mg}$. of $N^{1}$-methylnicotinamide chloride in $50 \mathrm{ml}$. of $0.1 \mathrm{~N}-\mathrm{HCl}$; (2) working standard solution, $2.5 \mu \mathrm{g} . / \mathrm{ml}$., made by diluting $1.0 \mathrm{ml}$. of the 'stock standard' to $200 \mathrm{ml}$. and containing $0.01 \mathrm{~N}-\mathrm{HCl}$.

\section{Procedure}

(a) Chemical. Take five $50 \mathrm{ml}$. conical flasks $(A-E)$. Flask $A$ is the blank, $B$ and $C$ are duplicate 'unknowns', $D$ and $E$ are duplicates containing the 'unknown + added standard'. Dilute the extract or solution of the test material so as to contain approximately $2 \cdot 5 \mu \mathrm{g}$. of $N-\mathrm{MN} / \mathrm{ml}$. To each flask add $2 \mathrm{ml}$. of the diluted solution.

To flask $A$ add $4 \mathrm{ml}$. of water, $0.5 \mathrm{ml}$. of $5 \mathrm{~N}-\mathrm{HCl}$ and $2 \mathrm{ml}$. of ketone. Heat for 5 min. on a boiling water bath. Evaporation is minimized by placing in the neck of the flask a simple three-bulb air condenser. Cool rapidly by adding $15 \mathrm{ml}$. of water, then $4 \mathrm{ml}$. of $\mathrm{KH}_{2} \mathrm{PO}_{4}$ solution. Make up to $40 \mathrm{ml}$. with water. The solution is then ready for reading.

To flasks $B$ and $C$ add $2 \mathrm{ml}$. of water; and to $D$ and $E 2 \mathrm{ml}$. of $N$-MN standard (i.e. $5 \mu \mathrm{g}$. of $N$-MN). Then to the four flasks add $2 \mathrm{ml}$. of ketone and $1 \mathrm{ml}$. of $5 \mathrm{~N}-\mathrm{NaOH}$. Wait exactly $5 \mathrm{~min}$., and then add $1.5 \mathrm{ml}$. of $5 \mathrm{~N}-\mathrm{HCl}$. Heat for 5 min. and proceed as for flask $A$.

(b) Fluorimetric. A single photo-cell fluorimeter (Cohen type) is used, together with a sensitive galvanometer (3800 mm./ 2 a., with light scale $2 \mathrm{~m}$. from mirror). The filters used are a 'Calorex' and a Wood's glass in the exciting beam of a mercury lamp. For the blue 'thiochromelike' fluorescence, Wratten filters nos. $2 \mathrm{~A}$ and 47 are placed in front of the photo cell. Readings are taken in cells of $20 \mathrm{ml}$. capacity.

Calculation. Let $X=$ galvanometer deflexion for flask $A$ (blank); $Y=$ mean of galvanometer deflexions for flasks $B$ and $C$ (unknown); $Z=$ mean of galvanometer deflexions for flasks $D$ and $E$ (unknown $+5 \mu \mathrm{g}$. of $N-\mathrm{MN}$ ); $R=$ dilution factor of original extract to obtain a suitable sample in 2 ml. of 'unknown'. Then the extract contains

$$
\frac{Y-X}{Z-Y} \times \frac{5}{2} \times R \mu \mathrm{g} .
$$

of $N^{1}$-methylnicotinamide/ml.

\section{Final procedure 2 ('decalso blank')}

In the procedure using the 'decalso blank', the 'no $\mathrm{NaOH}$ blank' in flask $A$ is replaced by a blank in which the fluorescence of a decalso filtrate is developed exactly as in flasks $B-E$.
Dilute a portion of the extract of the test material so as to contain approximately $2 \cdot 5 \mu \mathrm{g}$. of $N-\mathrm{MN} / \mathrm{ml}$. For the blank adjust another portion of the extract to $\mathrm{pH} 5$ with glacial acetic acid and make up to the same concentration as above.

Preparation of the blank. Take $20 \mathrm{ml}$. of the diluted solution adjusted to $\mathrm{pH}$ 5. Pass with suction through a column of decalso 60-80 mesh, $10 \mathrm{~cm}$. long, $8 \mathrm{~mm}$. in diameter, which has been previously washed with $10 \mathrm{ml}$. of water. Collect the filtrate.

Chemical. To flask $A$ add $2 \mathrm{ml}$. of the filtrate, and to flasks $B, C, D$ and $E 2 \mathrm{ml}$. of the diluted test material. To flask $A, B$ and $C$ add $2 \mathrm{ml}$. of water; and to $D$ and $E 2 \mathrm{ml}$. of $N$-MN standard. Then to all five flasks add $2 \mathrm{ml}$. of ketone and $1 \mathrm{ml}$. of $5 \mathrm{~N}-\mathrm{NaOH}$. Wait exactly $5 \mathrm{~min}$., and then add $1.5 \mathrm{ml}$. of $5 \mathrm{~N}-\mathrm{HCl}$. Heat for $5 \mathrm{~min}$. on a boiling water bath. Cool rapidly by adding $15 \mathrm{ml}$. of water, then $4 \mathrm{ml}$. of $\mathrm{KH}_{2} \mathrm{PO}_{4}$ solution. Make up to $40 \mathrm{ml}$. with water. Proceed with the fluorimetric readings and use the same calculations as in Procedure 1.

As a check for the complete adsorption of $N-\mathrm{MN}$ on the decalso column, take $20 \mathrm{ml}$. of the diluted test solution containing in addition $50 \mu \mathrm{g}$. of added $N-\mathrm{MN}$, and proceed with filtration through a decalso column. Add $2 \mathrm{ml}$. of the filtrate to a sixth flask $F$, and work through the method as for flask $A$. If the fluorescence resulting is greater than in flask $A$ the estimation must be repeated with a more dilute test solution so as to reduce its salinity.

\section{Reproducibility of fluorescence}

Using the results from thirty urine estimations, the standard deviation of the differences between the readings of duplicate flasks $B$ and $C$ was calculated, and found to be $\pm 2.9 \mathrm{~mm}$. The mean of all the readings was $66.7 \mathrm{~mm}$., so that the standard deviation for a single reading at the usual level of $N \cdot \mathrm{MN}$ may be expressed as $\pm 4.4 \%$ and the standard error of duplicate flasks as $\pm \frac{4 \cdot 4}{\sqrt{ } 2}= \pm 3 \cdot 1 \%$.

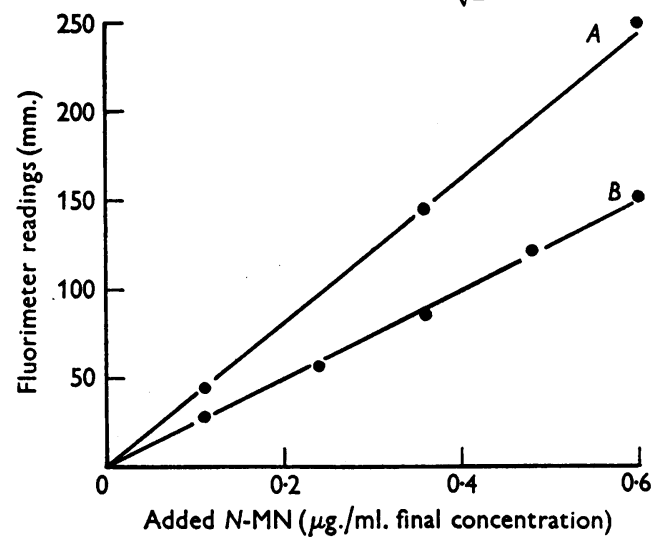

Fig. 1. Relation between concentration of $N-\mathrm{MN}$ and fluorescence, in aqueous medium and in the presence of urine; curve $A$, in water; curve $B$, in urine, diluted $1: 8$.

\section{Test of straight-line relationship}

The calculation described above does not depend upon a standard reference curve, but implied in it is a straight-line relation between concentration of $N-\mathrm{MN}$ and the galvanometer reading. This has been tested both in pure solution and in urine (Fig. 1). 
The results establish a straight-line relationship within the limits of the concentrations used for both urine and an aqueous solution of $N-M N$. It will be seen that the fluorescence of a given quantity of $\mathrm{N}-\mathrm{MN}$ is less in the presence of urine. This emphasizes the importance of an internal standard (Huff \& Perlzweig, 1947).

\section{Specificity}

Various substances were tested to see if they might interfere in the method. The following pyridine derivatives gave no fluorimeter reading in amounts of $20-80 \mu \mathrm{g}$.: nicotinic acid, nicotinic amide, nicotinic acid diethyl amide, trigonelline, nipecotic acid, picolinic acid, quinolinic acid, aminopyridine, pyridine, nicotine und sulphapyridine.

The following miscellaneous compounds also gave no fluorimeter readings when tested in biological concentrations: adenosine, adenylic acid, adenosinetriphosphoric acid (ATP), nucleic acid, indole-3-acetic acid, l-methyl indole acetic acid, glucose, urea, uric acid, $p$-aminobenzoic acid, inositol, pyridoxine, aneurin, riboflavin, pantothenic acid and choline.

Schweigert (1947) has reported that indole interferes in the acetone condensation method of Huff et al. (1945), itself giving rise to a fluorescence. We have obtained a similar fluorescence when testing indole with the acetone condensation method (Table 7), but the fluorescence was also present in the 'no NaOH blank', and could thus be eliminated. However, when using our methyl ethyl ketone method little or no fluorescence was given by indole when tested at a concentration of $5 \mu \mathrm{g} . / \mathrm{ml}$. final dilution. When using the 'no $\mathrm{NaOH}$ blank' which we recommend in our procedure, indole does not interfere with the estimation of $N$-MN.

Folic acid, pyridoxal and the oxidation product of pyridoxine at neutral pH gave a definite blue fluorescence. This, however, remained in all the blanks and so did not interfere with the $N-\mathrm{MN}$ results.

\section{Differentiation of $\mathrm{N}-M N$ from coenzyme $\mathrm{I}$ and $\mathrm{N}^{1}$-methylnicotinuric acid betaine}

Diphosphopyridine nucleotide preparations when tested gave a fluorescence. The fluorescent material, however, unlike $N$-MN, was not adsorbed on to the decalso column in the techniques described above (Table 8). Similarly, $N^{1}$. methylnicotinuric acid betaine gave a fluorescence, but was not adsorbed on the column (Table 9). This technique (Procedure 2) allowed a separate estimation of $N$-MN and

Table 7. Specificity test with indole

(a) Acetone-condensation method

Fluorimeter readings (mm.)

$\begin{array}{cccc} & \text { Indole } & & N-\mathrm{MN} \\ \text { Blanks } & (5 \mu \mathrm{g} \cdot / \mathrm{ml} .) & \text { Indole }(5 \mu \mathrm{g} . / \mathrm{ml} .)+N \cdot \mathrm{MN}(0 \cdot 1 \mu \mathrm{g} . / \mathrm{ml} .) & (0 \cdot 1 \mu \mathrm{g} . / \mathrm{ml} .) \\ \text { (1) Water } & 1 & 1 & 1 \\ \text { (2) No NaOH } & 12 & 12 & 1 \\ \text { Full fluorescence } & 13 \cdot 5 & 31 & 26 \cdot 5 \\ & (b) \text { Methyl ethyl ketone method } & \\ \text { Blanks } & 2 & 1 & 1 \\ \text { (1) Water } & 3 & 2 & 1 \\ \text { (2) No NaOH } & 3.5 & 45 & 44\end{array}$

Table 8. Differentiation of $\mathrm{N}-M N$ from coenzyme I (Co I) by decalso filtration

\begin{tabular}{|c|c|c|c|}
\hline \multirow[b]{2}{*}{ Materia] } & \multicolumn{3}{|c|}{ Fluorimeter reading (mm.) } \\
\hline & Procedure $1^{*}$ & Procedure $2 \dagger$ & $\begin{array}{l}\text { Difference } \\
\text { due to Co I }\end{array}$ \\
\hline $\begin{array}{l}N-\mathrm{MN}, 0 \cdot 1 \mu \mathrm{g} . / \mathrm{ml} . \\
\text { Co I }(50 \% \text { purity), } 1 \mu \mathrm{g} . / \mathrm{ml} . \\
N-\mathrm{MN}, 0 \cdot 1 \mu \mathrm{g} . / \mathrm{ml} .+ \text { Co I (50\% purity), } 1 \mu \mathrm{g} . / \mathrm{ml} \text {. }\end{array}$ & $\begin{array}{l}\mathbf{3 0} \cdot 0 \\
\mathbf{2 6} \cdot \mathbf{5} \\
\mathbf{5 5} \cdot \mathbf{2}\end{array}$ & $\begin{array}{r}30 \cdot 0 \\
-0 \cdot 7 \\
29 \cdot 0\end{array}$ & $\begin{array}{c}0 \\
27 \cdot 2 \\
26 \cdot 2\end{array}$ \\
\hline
\end{tabular}

Table 9. Fluorescence of $\mathrm{N}^{1}$-methylnicotinuric acid betaine with and without decalso treatment

\begin{tabular}{|c|c|c|c|c|}
\hline \multirow[b]{2}{*}{ Material } & \multicolumn{3}{|c|}{ Fluorimeter readings (mm.) } & \multirow{2}{*}{$\begin{array}{l}\text { Percentage } \\
\text { adsorbed } \\
\text { on decalso }\end{array}$} \\
\hline & $\begin{array}{l}\text { No } \mathrm{NaOH} \\
\text { blank }\end{array}$ & $\begin{array}{c}\text { Full } \\
\text { fluorescence }\end{array}$ & Increase & \\
\hline$N-\mathrm{MN}(0 \cdot 25 \mu \mathrm{g} . / \mathrm{ml})$. & $1 \cdot 5$ & $105 \cdot 5$ & 104 & - \\
\hline$N-\mathrm{MN}$, decalso filtered $(0.25 \mu \mathrm{g} . / \mathrm{ml})$. & 1.5 & 1.5 & 0 & 100 \\
\hline$N^{1}$-methylnicotinuric acid betaine $(0.31 \mu \mathrm{g} . / \mathrm{ml} .)^{*}$ & 2 & 26 & 24 & - \\
\hline$N^{1}$-methylnicotinuric acid betaine, decalso filtered & 2 & 26 & 24 & 0 \\
\hline
\end{tabular}

* Equimolecular to $0.25 \mu \mathrm{g}$. of N-MN. Prepared by Dr F. Bergel; m.p. $240^{\circ}$. (Found: C, 51, 22; H, 5.57; N, 13.4\%. Calc.: C, $50 \cdot 9 ; \mathrm{H}, 5 \cdot 66 ; \mathrm{N}, 13 \cdot 2 \%$.) 
the other $N^{1}$-substitute pyridine compounds. None of these substances gave a fluorescence with the 'no $\mathrm{NaOH}$ blank'. Hence, Procedure 1 (using 'no $\mathrm{NaOH}$ blank') gives a measure of the total fluorescence, while Procedure 2 (using 'decalso blank') measures only the fluorescence of $N$-MN. The difference between the two values is therefore a measure of the Co I or $N^{1}$-methylnicotinuric acid betaine content. The latter substance has so far as we know not been reported to occur in nature.

In studying a number of preparations of Co I of varying purity, we have found that the fluorescence given by the samples was not strictly related to its coenzyme content as determined spectrophotometrically or enzymically. It is possible that inactive breakdown products may give rise to fluorescence. This matter is under investigation and will be reported elsewhere.

\section{RESULTS}

The method has now been used for the determination of $N$-MN in several hundred samples of rat urines, and also in several examinations of human urines before and after test dosing with nicotinamide. Attempts were also made to estimate $N-\mathrm{MN}$ in rat livers.

Table 10. N-MN content of urines and livers. Results obtained with procedures 1 and 2

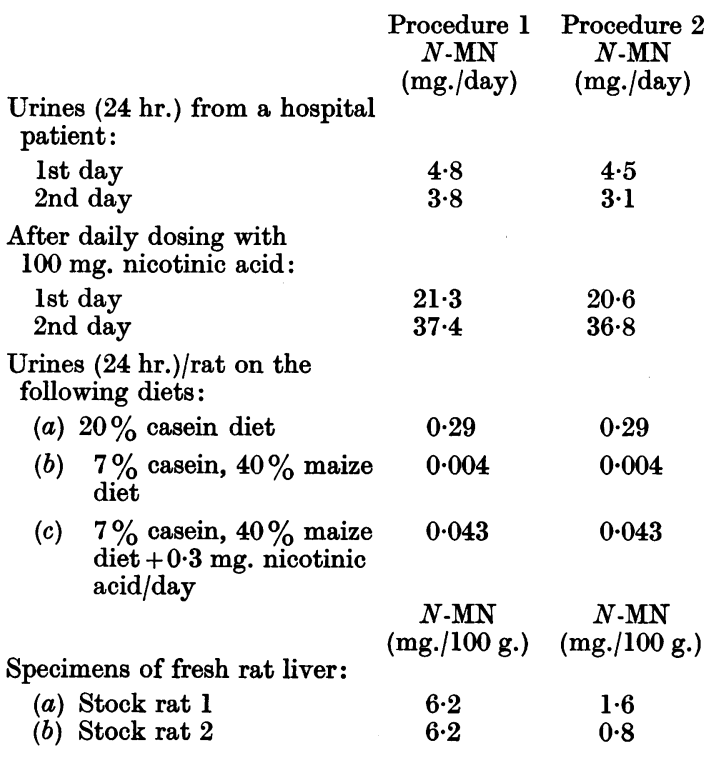

Table 10 shows that the use of the different blanks gave similar final values in the case of urine, and that the small differences remained fairly constant over a wide range of $N$-MN excretion. In the case of liver, however, Procedure 2 ('decalso blank') showed a far smaller value than the other procedure. Most of the fluorescence therefore was produced by a material which was not adsorbed on the decalso column. This compound, or compounds, showed the properties of Co I rather than $N$-MN.

\section{DISCUSSION}

The method as given above produces fluorescent substances probably from all compounds of the type

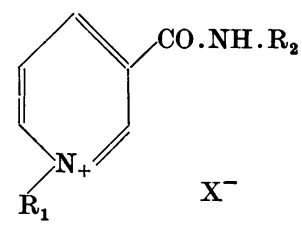

when treated with alkali and methyl ethyl ketone. Thus Co I and $N^{1}$-methylnicotinuric acid betaine give a distinct fluorescence.

The validity of the method depends upon the choice of a suitable blank procedure. Several possibilities have been examined. The procedure using the 'water blank' estimates materials which fluoresce on treatment with ketone but not without ketone; the procedure using the 'no $\mathrm{NaOH}$ blank' measures materials which fluoresce in ketone at acid $\mathrm{pH}$ only after a period in alkali; the procedure using the 'decalso blank' measures materials fluorescing with ketone under the conditions of the test, and which are also adsorbed on decalso.

It was found the Co I and $N^{1}$-methylnicotinuric acid betaine behave like $N$-MN with the 'water blank' and 'no $\mathrm{NaOH}$ blank' giving thus an apparent reading of $N$-MN. They were however not adsorbed on decalso and therefore it is possible to differentiate these two compounds from $N$-MN. For routine estimation of material where significant interference by coenzymes is not encountered the simpler procedure using the 'no $\mathrm{NaOH}$ blank' may be used.

In rat urine, Procedures 1 and 2 give identical results within the limits of experimental error. In human urine there was a fairly constant difference which did not increase on dosing with nicotinamide and may be explained by a small concentration of coenzyme in the urine. The difference of fluorescence between the 'water blank' and 'no $\mathrm{NaOH}$ blank' is also fairly constant and unaffected by dosing with nicotinamide. Thus it is apparently not connected with nicotinic acid metabolism.

The excretion of $N$-MN by rats maintained on various diets, similar to those reported by Kodicek, Carpenter \& Harris (1946, 1947), has been examined by this method. The ingestion of maize was found to lower the $N$-MN excretion to one-twentieth of that of rats on a simple casein-sucrose diet of similar protein and nicotinic acid content. Addition of nicotinic acid to the maize-containing diets increased the excretion tenfold. Similar findings, though without changes of such magnitude, have been reported by Ellinger (1946) and other workers. 


\section{SUMMARY}

1. A rapid and simple method for the estimation of $N^{1}$-methylnicotinamide is presented. It has been modified from the procedure described by Huff et al. (1945) by using methyl ethyl ketone instead of acetone, and by the adoption of two alternative blank procedures.

2. The conditions of the reaction and the specificity of the method have been studied.
3. With the blank procedures described the fluorescence due to coenzyme I and to $N^{1}$-methylnicotinuric acid betaine could be differentiated from that of $N^{1}$-methylnicotinamide.

4. Results of $N^{1}$-methylnicotinamide estimations have been reported for rat and human urines.

Our thanks are due to Dr Dorothy Needham and Dr W. K. Slater for kindly supplying us with samples of Co I. We are grateful to Dr F. Bergel of Roche Products, Ltd. for his synthesis of $N^{1}$-methylnicotinuric acid betaine.

\title{
REFERENCES
}

Coulson, R. A., Ellinger, P. \& Holden, M. (1944). Biochem. $J .38,150$.

Ellinger, P. (1946). Biochem. J. 40, xxxiii.

Ellinger, P. \& Coulson, R. A. (1943). Nature, Lond., 152, 383.

Huff, J. W. (1947). J. biol. Chem. 167, 151.

Huff, J. W. \& Perlzweig, W. A. (1943a). Science, 97, 538.

Huff, J. W. \& Perlzweig, W. A. (1943b). J. biol. Chem. 150, 395.

Huff, J. W. \& Perlzweig, W. A. (1943c). J. biol. Chem. 150, 483.

Huff, J. W. \& Perlzweig, W. A. (1944). Science, 100, 15.

Huff, J. W. \& Perlzweig, W. A. (1947). J. biol. Chem. 167, 157.

Huff, J. W., Perlzweig, W. A. \& Tilden, M. (1945). Fed. Proc. 4, 92.
Kodicek, E., Carpenter, K. J. \& Harris, L. J. (1946), Lancet, 251, 491.

Kodicek, E., Carpenter, K. J. \& Harris, L. J. (1947). Lancet, 252, 616.

Levitas, N., Robinson, J., Rosen, F., Huff, J. W. \& Perlzweig, W. A. (1947). J. biol. Chem. 167, 169.

Najjar, V. A. (1944). Bull. Johns Hopk. Hosp. 74, 392.

Najjar, V. A., Scott, D. B. M. \& Holt, L. E. (1943). Science, 97, 537.

Robinson, J., Levitas, N., Rosen, F. \& Perlzweig, W. A. (1947). J. biol. Chem. 170, 653.

Rosen, F., Huff, J. W. \& Perlzweig, W. A. (1946). J. biol. Chem. 163, 343.

Schweigert, B. S. (1947). Science, 106, 522.

\section{Studies in Immunochemistry}

\section{THE ISOLATION AND PROPERTIES OF THE HUMAN BLOOD-GROUP A SUBSTANCE}

\author{
By D. AMINOFF, W. T. J. MORGAN AND WINIFRED M. WATKINS \\ The Lister Institute of Preventive Medicine, London, S.W. 1
}

\section{(Received 7 November 1949)}

The earliest attempts to isolate and identify the substances responsible for the human specific bloodgroup characters were made by extracting erythrocytes with ethanol (Brahn \& Schiff, 1926; Dold \& Rosenberg, 1928; Hallauer, 1929, 1932, 1934; Ottensooser, 1932; Stepanov, Kuzin, Markageva \& Kosyakov, 1940). The group materials obtained were inhomogeneous, but the results demonstrated that the group substances could be isolated from red cells and were most probably of carbohydrate nature. There are special difficulties associated with the isolation of group substances from erythrocytes and it is now known that these materials are in some way bound up with the lipid constituents of the red. cell surface and are thus rendered water insoluble. Furthermore, the amount of the group substance present in the erythrocyte stroma is exceedingly small. For these and other reasons, methods for the isolation of the specific substances from human red cells are largely undeveloped, and little is known concerning the exact chemical nature of the groupspecific complexes on the erythrocyte surface.

The occurrence of the human blood-group substances in a water-soluble form in the tissue fluids and secretions of some individuals has been known for many years and our present knowledge of the human group substances has been obtained largely through a study of these water-soluble components. Landsteiner \& Harte (1941) isolated from saliva substances of mucoid nature which possessed group-specific serological characters, and similar materials were obtained from human urine by Freudenberg \& Eichel $(1934,1935)$ and by Freudenberg \& Molter (1939). Witebsky \& Klendshoj $(1940,1941)$ likewise isolated carbohydrate materials from the gastric juice of persons belonging to groups $\mathbf{B}$ and $\mathbf{O}$, but they were unable to obtain the group substances free from contaminating materials owing to the small amount of the specific factors available and the absence, at that time, 